\title{
Characteristics of microplastics in shoreline sediments from a tropical and urbanized beach (Da Nang, Vietnam)
}

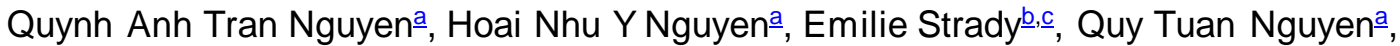 \\ Mau Trinh-Dang $\underline{\underline{a}}$, Van Minh Vo $\underline{a}, \underline{\underline{a}}$ \\ ${ }^{a}$ The University of Da Nang - University of Science and Education, 459 Ton Duc Thang, Danang, Viet Nam \\ ${ }^{\mathrm{b}}$ Aix-Marseille Univ., Mediterranean Institute of Oceanography (MIO), Marseille, Université de Toulon, CNRS/IRD, France \\ ${ }^{\mathrm{C}}$ CARE, Ho Chi Minh University of Technology, VNU-HCM, Viet Nam
}

\section{A R T I C LEIN F O}

\section{Keywords:}

Microplastics

Synthetic fibers

Concentration

Shoreline sediments

Sandy beach

Da Nang

\begin{abstract}
A B S TR A C T
Microplastics in shoreline sediments were investigated from Da Nang beach for the first time. Sediment samples at the two depth strata $(0-5 \mathrm{~cm}$ and $5-10 \mathrm{~cm})$ at eight sites along the entire coast were collected for identifying the characteristics of microplastics, including their concentration, size, shape, color, and nature. The synthetic fiber was the predominant type of microplastics, accounting for $99.2 \%$ of the total items. Blue (59.9\%) and white $(22.9 \%)$ were the most common colors of the fibers. Synthetic fibers showed a homogenous distribution at all sampling sites with a mean concentration of $9238 \pm 2097$ items $\mathrm{kg}^{-1} \mathrm{~d}$.w. Meanwhile, the fibers tended to concentrate much more at the surface stratum than the deeper stratum. A large number of synthetic fibers $(81.9 \%)$ were in the size range of $300-2600 \mu \mathrm{m}$, which might pose a threat to marine biota and human health.
\end{abstract}

\section{Introduction}

Microplastic pollution is an alarming problem that poses many threats to human health and to the ecosystem. With a size of between $1 \mu \mathrm{m}$ and $5 \mathrm{~mm}$ (Frias and Nash, 2019), microplastics (MPs) are widely distributed in the environment and can enter the human body and organisms through ingestion and inhalation to cause adverse impacts (Thompson et al., 2009). MPs have been detected in a variety of organisms at all trophic levels from zooplankton (Cole et al., 2013; Sun et al., 2017) to invertebrates (Setälä et al., 2016; Van Cauwenberghe et al., 2015), fishes (Neves et al., 2015; Vendel et al., 2017; Pazos et al.. 2017), birds (Amelineau et al., 2016; Provencher et al.. 2018), and mammals (Nelms et al., 2018; Nelms et al., 2019). Moreover, toxicity associated with plastics such as plastic additives or adhered pollutants absorbed in plastic particles (e.g. trace metals, endocrine-disrupting chemicals, POPs) may potentially impact higher trophic level species and human health through bioaccumulation and biomagnification processes via the food webs (Andrady, 2011; Wang et al., 2018). Adverse effects of MPs in organisms have been evidenced at different levels such as causing oxidative stress and histological changes, altering feeding preferences and behaviors, inhibiting incubation time and hatching of eggs, decreasing growth rate and survival rate (Lo and Chan, 2018; Luan et al., 2019; Wang et al., 2019; Cole et al.. 2015;
Lönnstedt and Eklöv, 2016; Lee et al., 2013; Carson et al., 2011).

Shorelines all over the world concentrate a large number of macroplastics as well as microplastics, which came from both anthropogenic activities inland and the sea (Ryan et al., 2009). Shoreline areas, especially beaches, are environments presenting ideal conditions (e.g. high irradiation and temperature, abundant wind, and waves) for the degradation of macroplastics into microplastics (Browne et al.. 2007). The widespread distribution of microplastics in the shoreline sediment has been reported in many areas all over the world such as the western Gulf of Lion, Northwestern Mediterranean Sea (Constant et al., 2019), Germany (Liebezeit and Dubaish, 2012), Canada (Mathalon and Hill, 2014), Brazil (Filho and Monteiro, 2019), Portugal (Martins and Sobral, 2011), Italy (Fischer et al., 2016), Orkney (Blumenröder et al., 2017), and China (Qiu et al., 2015). The abundance of MPs presents a wide range of concentrations from only a few particles (e.g. in Belgium; Claessens et al., 2011; Rusia; Esiukova, 2017; Portugal; Martins and Sobral, 2011) to thousands of particles per kilogram of dry weight sediment (e.g. in Tunisia; Abidli et al., 2017; Beibu Gulf, China; Qiu et al.. 2015; Canada; Mathalon and Hill, 2014).

While a huge amount of research on MPs in the shoreline sediment has been conducted in many countries in America and Europe, studies on MPs in South East Asia marine environment are still rare although MPs pollution in this region seems more serious. In fact, South East Asia

\footnotetext{
* Corresponding author.

E-mail addresses: tdmau@ued.udn.vn(M. Trinh-Dang), vominhdn@ued.udn.vn (V.M. Vo).
} 


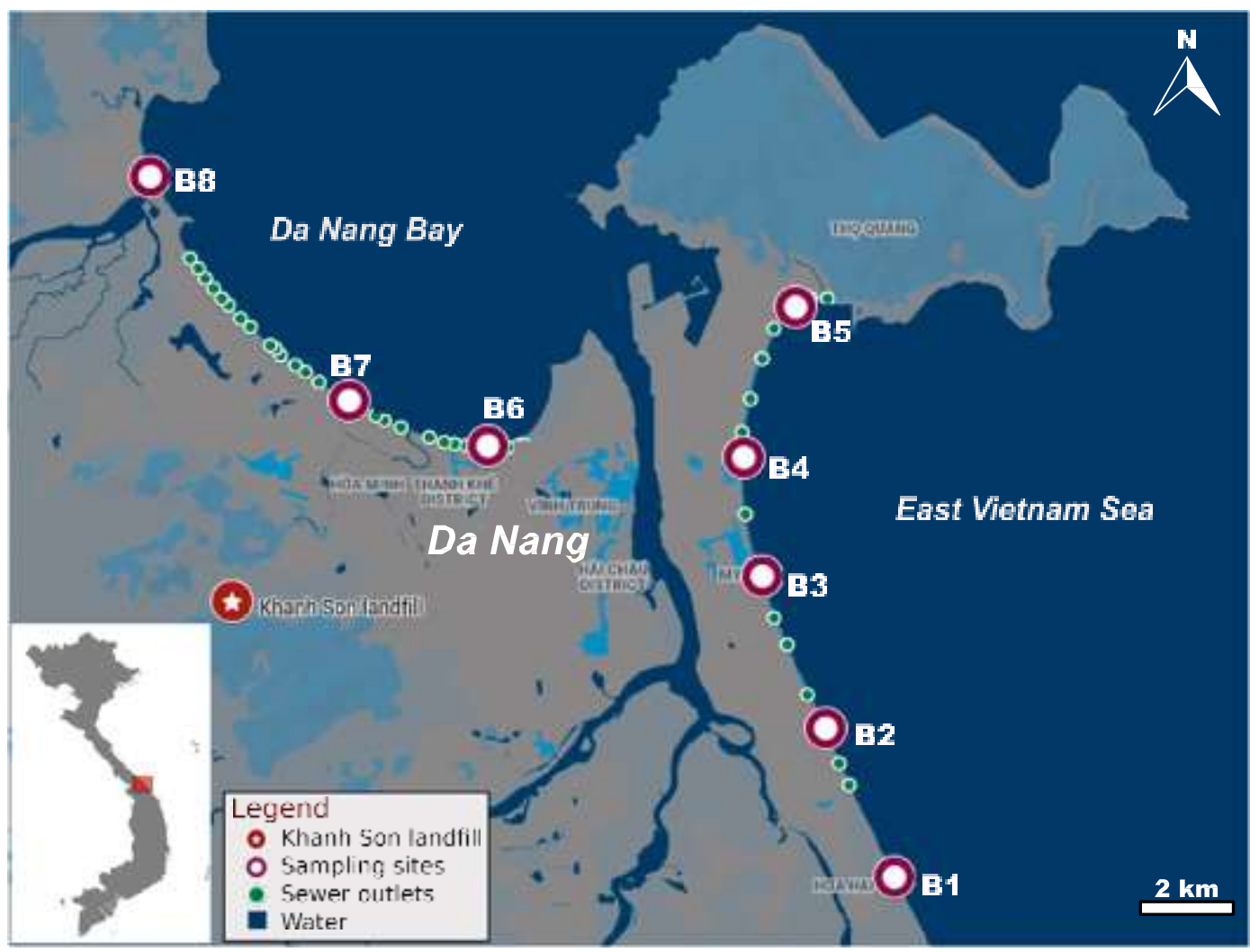

Fig. 1. Map of Da Nang shorelines and sampling sites.

accounts for half of the countries in the list of top 10 countries that release plastic to the ocean (Jambeck at el., 2015). According to Shim et al. (2018), the microplastic concentrations in beaches in Asia, especially East Asia, were significantly higher than those in countries in Europe, North and South America, North and South Pacific, Atlantic, and the Mediterranean. Hong Kong was identified as hotspots of marine plastic pollution with the density of MPs in the sediment of 25 beaches along the coastline reaching 5595 items $\mathrm{m}^{-2}$ (Fok and Cheung, 2015). Some other Asia countries with a high level of microplastic concentrations were China (5000-8714 items kg ${ }^{-1}$ sediment at Beibu Gulf areas; Qiu et al.. 2015), Japan (1900 items kg ${ }^{-1}$ sediment at Tokyo Bay; Matsuguma et al., 2017), and South Korea (large MPs (1-5 mm): 0 2088 items $\mathrm{m}^{-2}$, and small MPs $(0.02-1 \mathrm{~mm}): 1400-62,800$ items $\mathrm{m}^{-2}$ at 20 sandy beaches; Eo et al., 2018). Meanwhile, Singapore was the country with the lowest concentrations of MPs in the region (0-16 items $\mathrm{kg}^{-1}$ sediment in 2006; $\mathrm{Ng}$ and Obbard, 2006; and $36.8 \pm 23.6$ items $\mathrm{kg}^{-1}$ sediment in 2014; Nor and Obbard, 2014).

Vietnam is the third highest consumer of plastic in South East Asia (after Malaysia and Thailand) with a plastic consumer per capita of 41 $\mathrm{kg}$ in 2015 (increased 10 times more than that in 1990) (Lahens et al.. 2018). With more than 1.8 million tons of plastic waste generated per year and only $27 \%$ of them being recycled, plastic pollution has become a big problem that threatens the coastal area environment of the country. Vietnam has been identified as the 4th largest plastic emitting country in the world with an estimated $0.28-0.73$ million metric tons per year of plastics discharged into the marine environment (Jambeck et al., 2015). A survey conducted by IUCN and Greenhub (IUCN, 2019) showed that plastic items accounted for $92 \%$ of the total debris collected on the beaches of Vietnam. However, up to now, there is no information on microplastics distribution along the shorelines, which may cause difficulty for the government to take a comprehensive view of the current situation of plastic pollution as well as to have an effective management strategy. In such context, the purpose of this study is to estimate the concentration of microplastics $(300 \mu \mathrm{m}$ -
$5000 \mu \mathrm{m}$ ) in the surface sediment of an urbanized shoreline in Vietnam and to characterize the parameters that may influence their distribution along the shorelines. To do so, we selected sandy beaches along the shorelines of the coastal megacity of Da Nang and investigated the characteristics of the microplastics (concentration, size, shape, color, and nature).

\section{Materials and methods}

\section{Study sites and sample collection}

Da Nang is one of the biggest and major coastal cities of Vietnam with a total area of $1284.88 \mathrm{~km}^{2}$; a population of 1141130 people in 2019; and a density of 888.12 people $\mathrm{km}^{-2}$ (DSO (Danang Statistical Office), 2020). The city has a coastline of over $90 \mathrm{~km}$ (Thach and Nguyen, 2010) with many sandy beaches, which played an important role in the city's development. The shoreline area has an irregular semidiurnal tidal regime with an average tidal range of around $1 \mathrm{~m}$. The coastal water current is the predominantly southeast direction with an average speed of about $20-25 \mathrm{~cm} \mathrm{~s}^{-1}$ (Le, 2009). Da Nang is characterized by a tropical monsoon climate with two seasons in a year, a wet season from September-December, and a dry season from January-August. The area receives a total of $2319 \mathrm{~h}$ of sunshine and $2150 \mathrm{~mm}$ of rainfall, obtains an annual mean temperature of $27.3{ }^{\circ} \mathrm{C}$ and humidity of $78.3 \%$ in 2019 (DSO (Danang Statistical Office), 2020). Rapid urbanization (urbanization rate: $87.2 \%$ ) and the increase of economic development activities had put the coastal environment under many stresses. Every day, various kinds of solid waste and wastewater from the city and upstream areas are carried to the coastal areas and rushed along the shorelines. Tourism activities are important and contribute to waste emission with many resorts and bathing areas along the shoreline, as do fishery activities with waste emissions toward the coastal environment.

Eight sandy beach sites (B1 - B8) along the entire Da Nang coast 
Table 1

Geographical information of sampling sites.

\begin{tabular}{|c|c|c|c|}
\hline Sites code & Longitude & Latitude & Description \\
\hline B1 & 15.98817 & 108.2774 & Tan Tra beach - Resort area 16.01744 \\
\hline B2 & & 108.2633 & Son Thuy beach - Public bathing area \\
\hline B3 & 16.04755 & 108.2504 & My Khe beach - Resort area \\
\hline B4 & 16.07102 & 108.2466 & $\begin{array}{l}\text { Pham Van Dong beach - Public bathing } \\
\text { area }\end{array}$ \\
\hline B5 & 16.10054 & 108.2571 & Tho Quang beach - Fishery activities \\
\hline $\mathrm{B} 6$ & 16.07312 & 108.1940 & $\begin{array}{l}\text { Thanh Khe beach - Bathing, fishery } \\
\text { activities }\end{array}$ \\
\hline B7 & 16.08224 & 108.1656 & Hoa Minh beach - Public bathing area \\
\hline B8 & 16.12633 & 108.1245 & Nam O beach - Abandoned area \\
\hline
\end{tabular}

were selected for sampling in November 2019 (Fig. 1, Table 1). At each beach, a transect was plotted from the water edge to the position in front of the vegetation or artificial structure. For one site, five subsamples were collected at five equidistant locations along the transect and mixed together to obtain a homogeneous composite sample. Sediment samples were collected with a clean stainless steel hard tube (diameter $\times$ height: $6 \times 10 \mathrm{~cm}$ ) and a flat metal spatula at two depth strata separately, from the surface to $5 \mathrm{~cm}$ and from 5 to $10 \mathrm{~cm}$. The total volume of the sample at one site was about $700 \mathrm{~cm}^{3}$ for one depth stratum. Samples were then stored in closed clean glass bottles (Duran ${ }^{\circledast}$ bottle, $1000 \mathrm{~mL}$ ) and transported to the laboratory.

\subsection{Microplastics extraction, analysis, and observation}

Sediment samples were homogenized and dried at $55{ }^{\circ} \mathrm{C}$ for $72 \mathrm{~h}$ in a drying oven. Then, the extraction was performed on subsamples of $10 \mathrm{~g}$ of dry sediment. The digestion step was conducted by adding $\mathrm{H}_{2} \mathrm{O}_{2}$ $30 \%$ to the samples and keeping at $40{ }^{\circ} \mathrm{C}$ for $3 \mathrm{~h}$ to remove natural organic matters (Masura et al., 2015). The oxidized sediments were subsequently sieved with filtered water using a $300 \mu \mathrm{m}$ mesh size sieve. The fraction of the sample passed through the sieve $(<300 \mu \mathrm{m})$ was discarded because our target microplastic size was from 300 to 5000 $\mu \mathrm{m}$. Meanwhile, the sample fraction greater than $300 \mu \mathrm{m}$ retained on the sieve was kept for conducting the density separation step with filtered concentrated $\mathrm{NaCl}$ solution $\left(1.18 \mathrm{~g} \mathrm{~mL}^{-1}\right)$ by overflow producing technique (Hidalgo-Ruz et al., 2012). The overflow was conducted three times for each sample to have a good recovery of microplastics. Then, the solution containing MPs was filtered through glass fiber filters (GF/A, pore sizes of $1.6 \mu \mathrm{m}$ ) using a vacuum pump. Filters with MPs attached were kept in covered glass Petri dishes for identification of MPs characteristics.

A Leica S9i stereo-microscope equipped with a camera was employed for observing, analyzing, and photographing particle samples on the filters. MPs particles were categorized into five types of geometric shapes following the recommendation of GESAMP (2019) and Free et al. (2014): fragment, fiber, pellet, film, and foam. The sizes of all particles were measured using the LASX software ${ }^{\circledR}$. Since it is quite difficult to visually distinguish the nature of the particles when lower than $300 \mu \mathrm{m}$ length size, the size range of MP observation in this study was limited to $300 \mu \mathrm{m}$ to $5 \mathrm{~mm}$ for fibers and to 45,000 $\mu \mathrm{m}^{2}(300 \mu \mathrm{m} \times 150 \mu \mathrm{m})$ to $25,000,000 \mu \mathrm{m}^{2}(5000 \mu \mathrm{m} \times 5000 \mu \mathrm{m})$ for fragments. The concentration of MPs was expressed as items per kilo- gram of dry sediment (items $\mathrm{kg}^{-1}$ d.w.). Based on the recommendation of GESAMP (2019) for particles greater than $300 \mu \mathrm{m}$, we identified microplastic visually only using a stereomicroscope and we did not perform additional spectrometry analysis to identify systematically the nature of plastic. However, we isolated 10 items representing both the main types of fibers observed and for which their plastic nature needed to be validated. A XploRA ${ }^{\mathrm{TM}}$ PLUS Raman spectroscopy (Horiba ${ }^{\circledR}$ ), with $785 \mathrm{~nm}$ laser wavelength to eliminate luminescence signals, coupled to Raman Spectra Database Collection KnowltAll ${ }^{\circledR}$ was used to determine the polymer of the fibers selected. The fibers were Polyamides (PA, $n$ $=3$ ), Poly-ethylene vinyl alcohol copolymers (PVOH, $n=2)$, Polyester $(n=2)$, Polyethylene terephthalate (PET, $n=1)$, Polyacrylonitrile (PAN, $n=1)$, and Polyacrylate $(n=1)$, confirming our observation categorization as microplastics.

\section{Quality control}

To avoid microplastic's contamination from the ambient environment, a variety of rules have been strictly followed during the sampling and analytical process (GESAMP, 2019; Dehaut et al., 2019): cleaning the working area with alcohol before carrying out the procedure, wearing of cotton lab clothes and gloves, using glass or metal equipment and containers for sampling and analyzing, previous rinsing with filtered water (tap water filtered through GF/A filters) of glassware, previous filtration of solution (using GF/A filters), checking filters and sieves under a microscope prior to use, covering samples with aluminum foil, ban of fans in the lab. Atmospheric control tests and blank samples (Dehaut et al., 2019) were conducted during the analytical process and evidenced only 2 microfibers in the blank samples. The blank results were not retrieved from the sample concentrations measured.

\section{Data analysis}

All data analyses were performed using $R$ software ( $\mathrm{R}$ Core Team, 2018). One-way analysis of variance (ANOVA) was used to identify the variation in MPs concentrations, and $p$-values of less than 0.05 were regarded as significant. Data were presented as mean \pm standard deviation (SD).

\section{Results}

\section{Concentrations of microplastics}

Microplastics were found in all sediment samples from Da Nang beaches with a total number of 745 items. Fibers were the predominant type of microplastic found at two depth strata and at all sampling sites, comprising up to $99.2 \%$ of the total identified items (Fig. 2). Fragments ( $n=6$ items) accounted for $0.8 \%$ of the total MPs, and all of them were only found at the surface stratum $(0-5 \mathrm{~cm})$. The other shapes (pellets,

foam, and film) were not detected at all sampling sites. Accordingly, because of the quasi absence of fragments, we will consider later on that concentrations of microplastics are equal to the concentrations of fibers. The mean concentration of microfibers at Da Nang beach was $9238 \pm$

2097 items kg-1 d.w. Except for B6 site which exhibited the lowest

concentrations (5100 items $\mathrm{kg}^{-1}$ d.w.), the concentrations at the

remaining sites (B1-B5, B7-B8) were rather similar and ranged from 9000 to 11,000 items $\mathrm{kg}^{-1}$ d.w., indicating a homogenous distribution of microfibers in the shorelines of Da Nang (Fig. 3).

However, considering the depth distribution, the concentration of microfibers at the $0-5 \mathrm{~cm}$ depth stratum $\left(5750 \pm 1732\right.$ items $\mathrm{kg}^{-1}$ d.w.) was higher than that at the $5-10 \mathrm{~cm}$ stratum $(3488 \pm 1585$ items $\mathrm{kg}^{-1}$ d.w.), and accounted for $62.2 \pm 12.5 \%$ of the total microfibers (Fig. 4). This trend was observed in most sites of Da Nang beach, demonstrating that the surface sediment was more concentrated in microplastics than the underlying sediment layer.

\section{Colors}

Microfibers occurred in a variety of colors, including red, yellow, green, blue, purple, and white (Fig. 2). Blue was the most common color $(59.9 \%)$, followed by white $(22.9 \%)$. The other colors were only found with a small ratio (red $-8.2 \%$, yellow $-6.8 \%$, purple $-1.4 \%$, and green $-0.7 \%$ ). This color order of distribution was quite similar among sampling sites and also at both sediment layers (Fig. 3). 


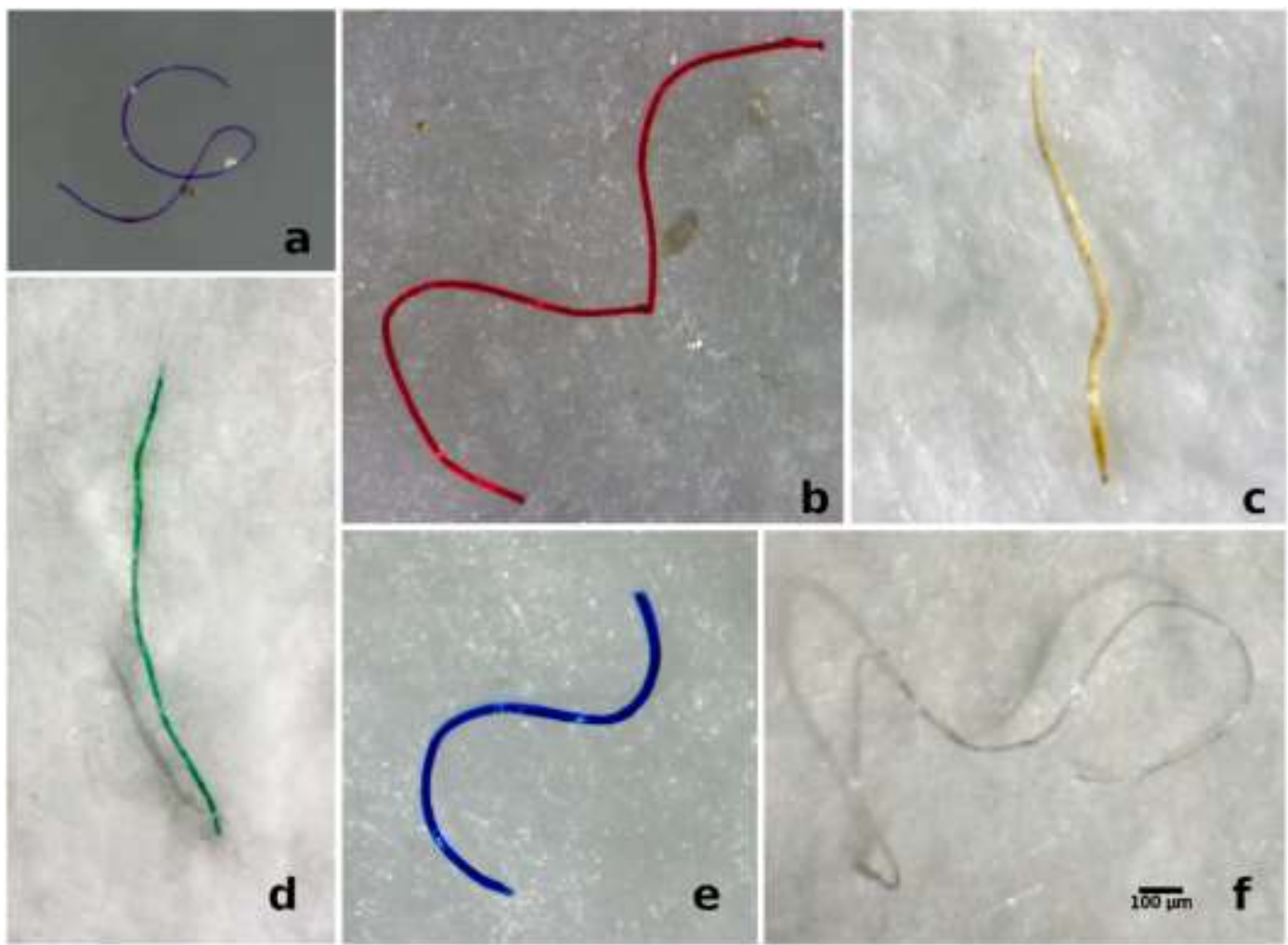

Fig. 2. Observed microplastics in Da Nang shoreline sediments (scale bar: $100 \mu \mathrm{m}$ for all photos from a to f).

\subsection{Size}

Microfibers in Da Nang beaches had a wide range of sizes with an average length of $1701 \pm 1029 \mu \mathrm{m}$ (min-max: $303 \mu \mathrm{m}-4996 \mu \mathrm{m})$ and an average diameter of $19.58 \pm 9.27 \mu \mathrm{m}$ (min-max: $4 \mu \mathrm{m}-79 \mu \mathrm{m})$. The mean length and diameter of microfibers among the eight sampling sites were rather similar, whereas the mean length of microfibers in the shallow layer $(0-5 \mathrm{~cm})$ was significantly shorter than that in the deeper layer $(5-10 \mathrm{~cm})(1596.3 \pm 982.7 \mu \mathrm{m}<1900 \pm 1046.1 \mu \mathrm{m}$, $\left.p=1.47 \times \mathrm{e}^{-5}<0.05\right)$. In the $0-5 \mathrm{~cm}$ depth stratum, the most frequent size of fibers was in the range 300-2100 $\mu \mathrm{m}$ (accounted for $76.1 \%$ of total microfiber observed in the layer), and the highest ratio of fiber number was in the length of 1000-1100 $\mu \mathrm{m}$ (34 fibers, accounted for $7.4 \%$ of the total). Meanwhile, in the $5-10 \mathrm{~cm}$ depth stratum, $76.3 \%$ of fiber was in the length from 500 to $2600 \mu \mathrm{m}$ and the most dominant length was 1200-1300 $\mu \mathrm{m}$ (Fig. 5). Regarding fiber diameter distribution, there was no significant difference between the two depth strata (Fig. 6). The predominant fiber's diameter was from 5 to $30 \mu \mathrm{m}(89.1 \%)$ in the surface stratum and from 5 to $35 \mu \mathrm{m}(96.8 \%)$ in the deeper stratum. Moreover, the diameter group of 15-20 $\mu \mathrm{m}$ was the most common size in Da Nang beach sediment, which accounted for $25 \%$ and $29.4 \%$ of the total microfibers in stratum $0-5 \mathrm{~cm}$ and $5-10 \mathrm{~cm}$, respectively.

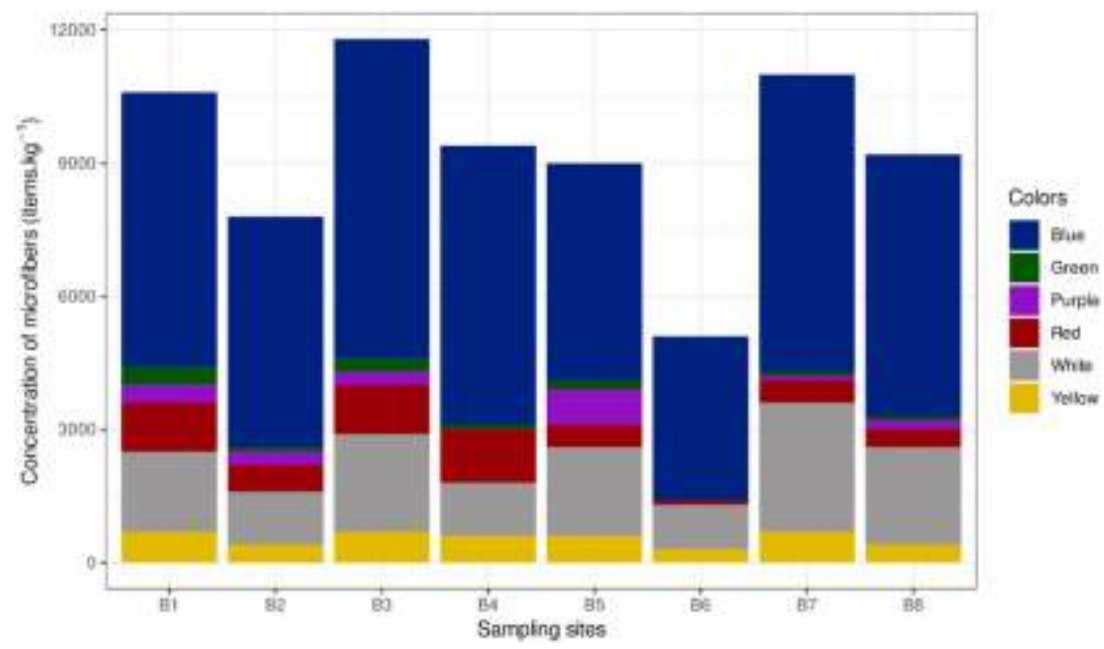

Fig. 3. Concentrations of microfibers (in items $\mathrm{kg}^{-1}$ d.w.) and associated color distribution at the eight sampling sites along the Da Nang shorelines. 


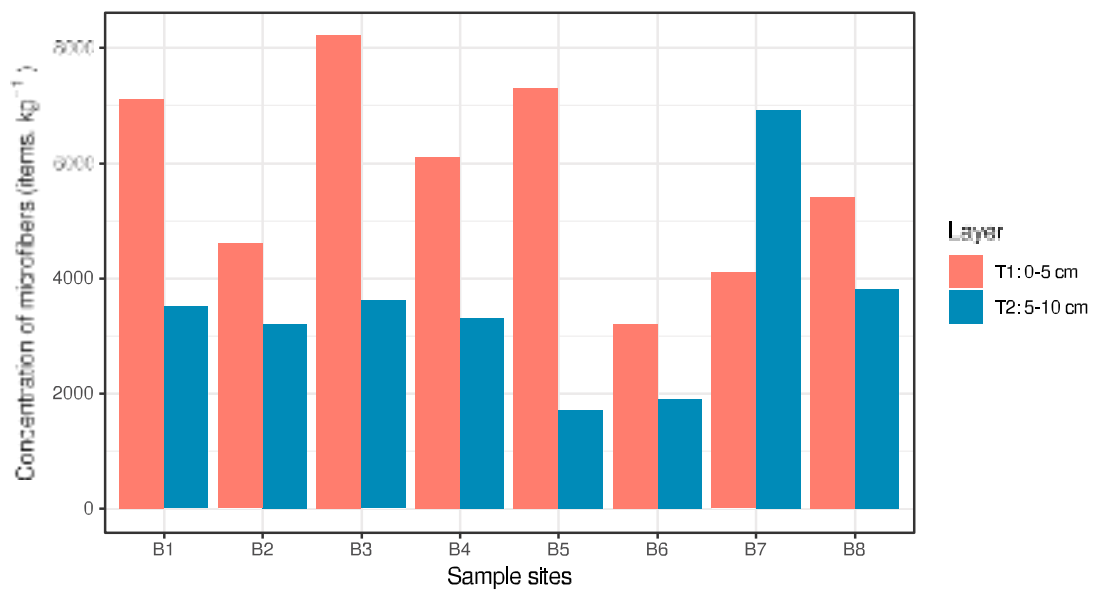

Fig. 4. Concentrations of microfibers measured at each sampling site for each sediment layer: T1: $0-5 \mathrm{~cm}$ and T2: 5-10 cm.
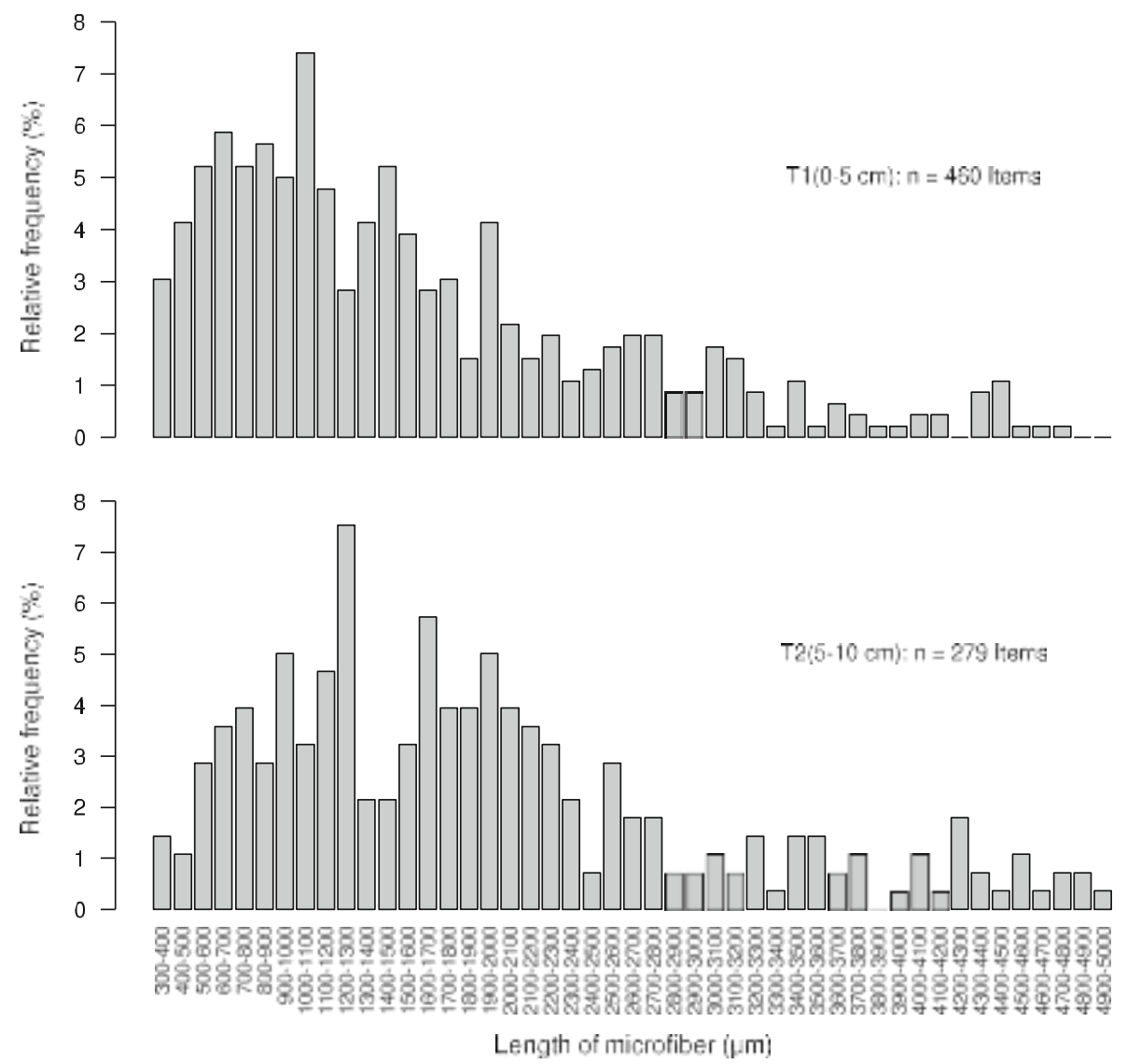

Fig. 5. Relative frequency of fibers length by size class cumulated for all samples on the two distinct strata (T1: $0-5 \mathrm{~cm}$ and $\mathrm{T} 2: 5-10 \mathrm{~cm}$ ).

\section{Discussion}

1. Dominance of synthetic fibers among the microplastics observed

Microplastics in Da Nang shoreline were mainly composed of fibers while the other shapes did not or occurred at a percentage lower than $1 \%$. This pattern of shape's distribution is similar to microplastics observed in the tropical Corvina beach, northern Brazilian coast, where microfibers accounted for $95 \%$ of the total MPs particles, followed by fragments $(\sim 5 \%)$, and pellets $(<0.01 \%)$ (Filho and Monteiro, 2019 ) and in temperate European beach sediments composed of $98.7 \%$ of $\mathrm{fi}$ bers, $0.4 \%$ of films, and $0.9 \%$ of fragments (Lots et al., 2017). Synthetic fibers (i.e. from petrochemical origin: polyester, polyamide, polypropylene, etc.) are considered with artificial fibers (i.e. from artificial cellulose or silk e.g. viscose, rayon) and with the natural fibers (e.g. cotton, wool) as anthropogenic fibers (Strady et al., 2020). Anthropogenic fibers, and so synthetic fibers, are all used in the textile and apparel industries. The predominance of synthetic fibers in a lesser extent in comparison to the other shapes was reported at many beach sediment from countries worldwide such as Tunisia (71-99\%; Abidli et al.. 2018), Slovenia (75-96\%; Laglbauer et al., 2014), Mexico (91\%; Piñon-Colin et al., 2018), South Africa (more than 90\%; Nel and Froneman, 2015), France (59-77\%; Constant et al., 2019), and the southeastern United States (Yu et al., 2018). In Asia, synthetic fibers were also the common type of MPs found in beach sediments in Singapore (72\%; Nor and Obbard, 2014), China (Qiu et al., 2015), India 

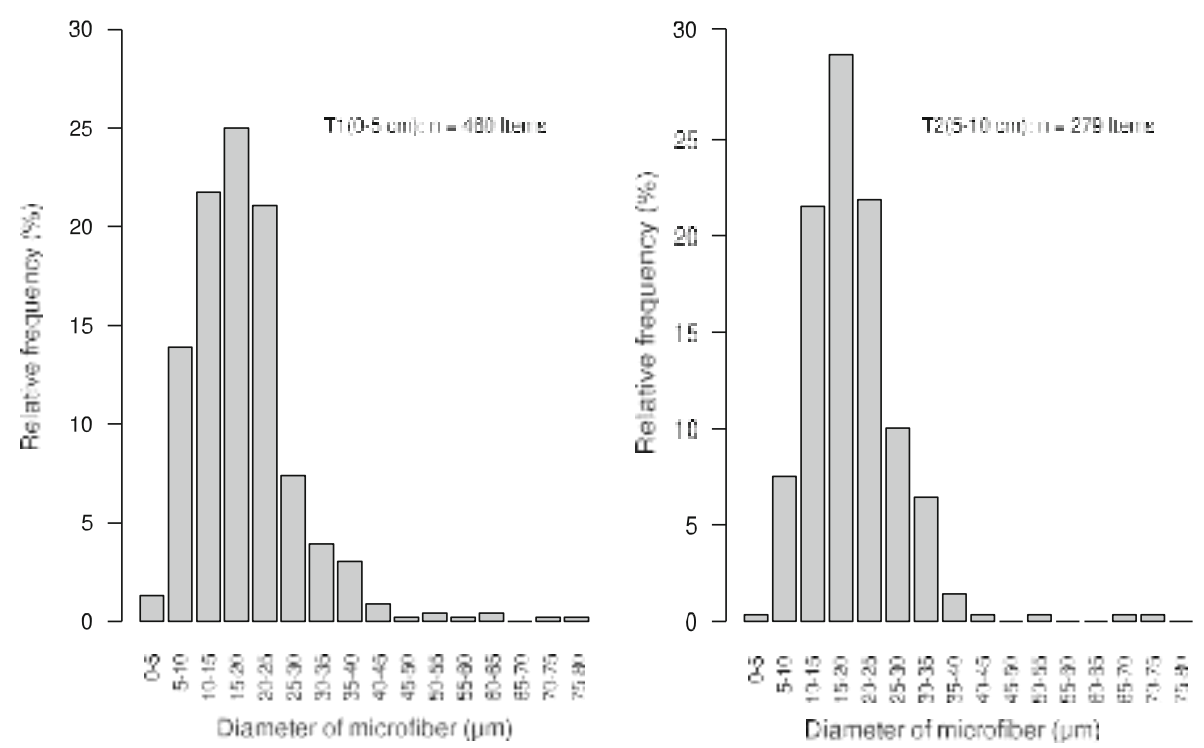

Fig. 6. Relative frequency of fibers diameter by size class cumulated for all samples on the two distinct strata (T1: $0-5 \mathrm{~cm}$ and T2: 5-10 cm).

(51\%; Tiwari et al., 2019), Hong Kong (57.2\%; Lo et al., 2018), and Dubai, UAE (63.9\%; Aslam et al., 2020). Sandy beaches from nine countries located around the Indian Ocean (including Australia, Bangladesh, India, Indonesia, Maldives, Myanmar, Pakistan, Sri Lanka, and Tanzania) were also reported to contain only synthetic fibers (Balasubramaniam and Phillott, 2016).

\subsection{Comparison of microplastic concentrations to worldwide beach sediments}

Measured microplastic concentrations can vary because of the sampling protocols (e.g. sediment depth, pooling of sediment, location on the shoreline), the methodologies used in the laboratory (e.g. separation technique used, sieving), and the size range of observation (Table 2). So far, most investigations targeted size range from $1 \mu \mathrm{m}$ to $5000 \mu \mathrm{m}$ (Qiu et al., 2015; Yu et al., 2016; Lo et al., 2018; Aslam et al., 2020), while some targeted $1 \mu \mathrm{m}$ to $1000 \mu \mathrm{m}$ (Claessens et al., 2011; Dekiff et al., 2014; Balasubramaniam and Phillott, 2016) or $300 \mu \mathrm{m}$ to $5000 \mu \mathrm{m}$ (Laglbauer et al., 2014; Esiukova, 2017; Matsuguma et al.. 2017). Those differences can thus induced a bias in the comparison of concentrations between sites. Therefore, some important parameters influencing the final concentrations were mentioned in the Table 2 to make the comparison more accurate.

Concentrations of MPs in surface shoreline sediments from Asian countries are shown on Table 2. A similar range of concentrations (6870 \pm 6140 items $\mathrm{kg}^{-1}$ d.w.; min-max: 5014-8714 items kg ${ }^{-1}$ d.w.) to our study ( $9238 \pm 2097$ items $\mathrm{kg}^{-1}$ d.w.) was observed in beach sediments from the Beibu Gulf and the coast of the South China Sea (Qiu et al.. 2015), located nearby human activities, despite that the range of MPs observation was broader than the one of our study (Table 2). In surface beach sediment from India, lower microplastic concentrations than in Da Nang were measured despite that the beaches were impacted by different anthropogenic activities like an urban area (Mumbai, $220 \pm 50$ items $\mathrm{kg}^{-1}$ d.w.), port and industrial areas (Tuticorin, $181 \pm 60$ items $\mathrm{kg}^{-1}$ d.w.), and tourism and fishing areas (Dhanushkodi, $45 \pm 12$ items $\mathrm{kg}^{-1}$ d.w.) (Tiwari et al., 2019) or Canacona city (520 items $\mathrm{kg}^{-1}$ d.w.; Balasubramaniam and Phillott. 2016). The MPs concentrations measured in other Asian beaches from Indonesia, Myanmar, Pakistan, Sri Lanka, Singapore, Japan, and Dubai were also one order of magnitude lower than the ones in Da Nang, despite again that the range of MPs observation was broader than our (Balasubramaniam and Phillott, 2016; Nor and Obbard, 2014; $\mathrm{Ng}$ and

Obbard. 2006; Matsuguma et al.. 2017) (Table 2). The same observations were made in other beaches from other continents like in Argentina (46.0 $\pm \quad 34.8$ to $86.2 \pm 66.1$ items kg ${ }^{-1}$ d.w.; Reis, 2019), in Belgium (52.8-213.4 items kg-1 d.w; Claessens et al., 2011), Slovenia (213.2 items $\mathrm{kg}^{-1}$ d.w.; Laglbauer et al., 2014), Germany (13532 items kg ${ }^{-1}$ d.w.; Stolte et al., 2015), Russia (1.3-36.3 items $\mathrm{kg}^{-1}$ d.w.; Esiukova, 2017), Romania (193.2-3606.8 items kg-1 d.w.; Popa et al., 2014), in Mexico (min-max: $16 \pm 4-312 \pm 145$ items $\mathrm{kg}^{-1}$ d.w., mean: $162 \pm 150$ items $\mathrm{kg}^{-1}$ d.w.; Piñon-Colin et al., 2018). We note that the inhabitant population in touristic beaches of Mexico was lower than in Da Nang (until 251,871 inhabitants com- pared to $1,141,130$ in $\mathrm{Da}$ Nang), pointing out the possible influence of population density on the observed concentrations. Same range of fiber concentrations than in Da Nang were recorded only in the Halifax Harbor in Canada (8000 items kg ${ }^{-1}$ d.w.; Mathalon and Hill, 2014).

\subsection{Sources of microplastic in Da Nang shoreline beaches}

The occurrence of synthetic fibers at Da Nang shoreline might be attributed to the discharge of domestic wastewaters to the beach (Horton et al., 2017). The effluents from clothes washing processes were identified as an important emission source of synthetic fibers (Browne et al., 2011; Napper and Thompson, 2016; De Falco et al.. 2018), and since the wastewater treatment plants in Da Nang are applying basic treatment, they cannot remove all the MPs from the wastewater (Gogina and Quan, 2018; Filgueiras et al., 2019; Browne et al.. 2011). Currently, Da Nang has 16 coastal wards with more than 30,570 households with many tourist accommodation establishments, which are partially connected to the city sewer system and which directly discharged domestic wastewaters (both treated and untreated) to the shorelines via 44 sewer outlets (Fig. 1.) (Da Nang DONRE (Department of Natural Resources and Environment Da Nang), 2018). During the rainy season and the high tourist season, the overflow of wastewaters often occurs at the shorelines, adding more MPs to the beach. Moreover, industrial wastewaters from the textile and garment industry ( 178 enterprises in 2019; DSO (Danang Statistical Office), 2020) are possibly another source of synthetic microfibers in Da Nang beach. The industrial wastewaters after treatment (and also without treatment) are discharged into the Han and $\mathrm{Cu}$ De Rivers and reach the bays and the beach ( $\mathrm{Da}$ Nang DONRE (Department of Natural Resources and Environment Da Nang), 2018). The diameters of synthetic fibers measured in Da Nang beach (median: $18 \mu \mathrm{m}$, mean: $19.58 \pm 9.27 \mu \mathrm{m}$; Fig. 6) were relatively similar to diameters of microfibers released in wastewaters from laundry activities (11.9-17.7 $\mu \mathrm{m}$; Napper and 
Table 2

Concentration of microplastics in surface shoreline sediments from Asia countries (n.a.: Not available).

\begin{tabular}{|c|c|c|c|c|c|c|}
\hline Location & Habitat & $\begin{array}{l}\text { MPs size } \\
\text { range }(\mu \mathrm{m})\end{array}$ & $\begin{array}{l}\text { Sampling } \\
\text { depth }(\mathrm{cm})\end{array}$ & Type of MPs & $\begin{array}{l}\text { Microplastics (mean } \pm \text { SD, min - max) } \\
\text { (items } \mathrm{kg}^{-1} \text { d.w.) }\end{array}$ & References \\
\hline Vietnam, Da Nang & Sandy beach & $300-5000$ & $\begin{array}{l}0-5 \& \\
0-10\end{array}$ & Fibers & $\begin{array}{r}9238 \pm 2097 \\
(5100-11,000)\end{array}$ & This study \\
\hline $\begin{array}{l}\text { China, Beibu Gulf and } \\
\text { coast of the South Sea }\end{array}$ & Beach & $1-5000$ & $0-1$ & Fibers, granules, films & $\begin{array}{l}6870 \pm 6140 \\
(5014-8714)\end{array}$ & $\underline{\text { Qiu et al., } 2015}$ \\
\hline China, Bohai Sea & Sandy beach & $1-5000$ & $\begin{array}{l}0-2 \& \\
0-20\end{array}$ & Fragments, sheets, fibers & $102.9 \pm \quad 39.9-163.3 \pm 37.7$ & $\underline{\text { Yu et al., } 2016}$ \\
\hline China, Hong Kong & $\begin{array}{l}\text {-Sandy beach } \\
\text {-Mudflats }\end{array}$ & $1-5000$ & $2-3$ & $\begin{array}{l}\text { Fibers }(57.2 \%) \text {, fragments } \\
(37.6 \%) \text {, films }(2.4 \%) \text {, } \\
\text { foams }(2.2 \%) \text {, pellets } \\
(0.3 \%) \text {. }\end{array}$ & $\begin{array}{l}16.8 \pm 5 \\
(0.58-98.6)\end{array}$ & Lo et al., 2018 \\
\hline & & & & & $268 \pm 44.5$ & \\
\hline $\begin{array}{l}\text { India: -Mumbai } \\
\text {-Tuticorin, } \\
\text {-Dhanushkodi }\end{array}$ & Sandy beach & $36-5000$ & $3-4$ & $\begin{array}{l}\text { Fibers }(51 \%) \text {, granules } \\
(40 \%) \text {, films }(9 \%)\end{array}$ & $\begin{array}{l}220 \pm 50 \\
181 \pm 60 \\
45 \pm 12\end{array}$ & $\underline{\text { Tiwari et al., } 2019}$ \\
\hline India, Palolem Beach & Sandy beach & $1-1000$ & $0-1$ & Fibers & 520 & $\begin{array}{l}\text { Balasubramaniam and } \\
\text { Phillott, } 2016\end{array}$ \\
\hline Indonesia, Ngebum Beach & Sandy beach & $1-1000$ & $0-1$ & Fibers & 172 & $\begin{array}{l}\text { Balasubramaniam and } \\
\text { Phillott, } 2016\end{array}$ \\
\hline Myanmar, Napoli Beach & Sandy beach & $1-1000$ & $0-1$ & Fibers & 132 & $\begin{array}{l}\text { Balasubramaniam and } \\
\text { Phillott, } 2016\end{array}$ \\
\hline $\begin{array}{l}\text { Pakistan, Hawkesbay } \\
\text { Beach }\end{array}$ & Sandy beach & $1-1000$ & $0-1$ & Fibers & 480 & $\begin{array}{l}\text { Balasubramaniam and } \\
\text { Phillott, } 2016\end{array}$ \\
\hline $\begin{array}{l}\text { Sri Lanka, Thumpalai } \\
\text { Beach }\end{array}$ & Sandy beach & $1-1000$ & $0-1$ & Fibers & 384 & $\begin{array}{l}\text { Balasubramaniam and } \\
\underline{\text { Phillott, } 2016}\end{array}$ \\
\hline Singapore & $\begin{array}{l}\text { Intertidal } \\
\text { mangroves }\end{array}$ & $1-5000$ & $3-4$ & $\begin{array}{l}\text { Fibers }(72.0 \%) \text {, films } \\
(23.3 \%) \text {, granules }(4.7 \%)\end{array}$ & $\begin{array}{l}36.8 \pm 23.6 \\
(12.0 \pm \quad 8.0-62.7 \pm 27.2)\end{array}$ & Nor and Obbard, 2014 \\
\hline Singapore & Beach & $1.6-5000$ & $0-1 \&$ & n.a. & $0-16$ & $\underline{\mathrm{Ng} \text { and Obbard, } 2006}$ \\
\hline Japan, Tokyo Bay & Canal & $315-5000$ & & $\begin{array}{l}\text { Fragments }(75 \%) \text {, fibers } \\
(15 \%), \text { beads }(4 \%)\end{array}$ & 1800 & Matsuguma et al., 2017 \\
\hline Dubai, UAE & Sandy beach & $1-5000$ & $0-1$ & $\begin{array}{l}\text { Fibers }(63.9 \%) \text {, fragments } \\
(20.5 \%), \text { string }(14.1 \%), \\
\text { polystyrene spheres } \\
(1.5 \%)\end{array}$ & 59.71 & Aslam et al., 2020 \\
\hline
\end{tabular}

Thompson, 2016; $14 \pm 3 \mu \mathrm{m}$ to $20 \pm 6 \mu \mathrm{m}$; De Falco et al., 2018). Small diameters support also fiber suspension in the water column and transportation through a long distance from generation sources to the beach (Waldschlager and Schüttrumpf, 2019). Therefore, we suggest that microfibers sampled in the beach can originate from domestic and industrial wastewaters.

Aside from domestic and industrial wastewaters, solid waste and landfill leachate might also contribute to MPs release to the environment and then to the beach (Horton et al., 2017). The daily amount of plastic waste generated in Da Nang in 2019 was estimated from 172 to 189 tons per day $(11 \%$ of the total domestic solid waste; Da Nang URENCO (Da Nang Urban Environment Company), 2019, 2019; Tran. 2019), equivalent to $0.15-0.17 \mathrm{~kg} \mathrm{cap}^{-1} \mathrm{day}^{-1}$, which is pretty high in comparison to other Asian and African countries (Ritchie and Roser, 2018). Although the city has been conducting many programs to manage plastic waste, they have not been systematically efficient and a large amount of plastic waste is still emitted to the surrounding environment and can be broken down into microplastics. Most of the collected plastic waste are buried together with other types of domestic solid waste in the city's landfill ( $\sim \mathrm{km}$ from Da Nang Bay, Fig. 1), where they might decompose into microplastics and leak into the landfill leachate (He et al., 2019). At present, the landfill leachates after being treated are conveyed to urban canals and discharged to the beaches ( $\mathrm{Da}$ Nang DONRE (Department of Natural Resources and Environment Da Nang), 2018). Finally, ghost nets from fishery activities could be also a main contributor to the anthropogenic fibers pollution observed on the beach sites (Horton et al., 2017; Lusher et al.. 2017). They are omnipresent in Da Nang beaches despite punctual clean-up campaigns.

\subsection{Spatial and vertical concentrations of microplastic in the sediments}

MPs were measured in the eight sampling sites and were similar in terms of shape, color, and concentrations, demonstrating a homogenous distribution for the entire shorelines. Those observations are quite unexpected, as the sites are subjected to different land use and beach waste management (touristic zone versus abandoned area) as well as received unalike pollution sources (Table 1).

However, regarding depth distribution, microplastic concentrations in the upper sediment layer $(0-5 \mathrm{~cm})$ were systematically higher than those in the lower layer $(5-10 \mathrm{~cm})$, which is in accordance with the observation by $\mathrm{Yu}$ et al. (2016) in Bohai beach sediments. In deeper beach sediments, the abundance of microplastic decreased significantly with depth in the Amazon macrotidal sandy beach $(61.5 \%, 25.0 \%$, and $13.5 \%$ from the surface to $20,20-40$, and $40-60 \mathrm{~cm}$; Filho and Monteiro, 2019) and in sandy beaches of Brazil (Turra et al., 2014). The authors evidenced that this trend might be related to the combination of phenomena like the surface layer exchanges directly with the seawater or wastewater which might retain more microplastics, or the larger plastics in the top layer that could be ground to smaller particles by people's activities at the surface (Yu et al., 2016). This might also explain the reason why the length of microfibers in our study site in the top $5 \mathrm{~cm}$ depth was shorter than that in the deeper layer $(5-10 \mathrm{~cm})$ (Fig. 5).

Synthetic fibers at Da Nang beaches had a median length size of $1456 \mu \mathrm{m}$ and a mean length size of $1701 \pm 1029 \mu \mathrm{m}$ (Fig. 5), which is rather similar to the size of microfibers in the South Tunisia lagoon $(1390 \pm 270 \mu \mathrm{m}$; Abidli et al., 2017). Besides, it should be noticed that $81.9 \%$ of fibers were in the range from 300 to $2600 \mu \mathrm{m}$, while the longer fibers (from 2600 to $5000 \mu \mathrm{m}$ ) only accounted for a low ratio. 
This trend of size distribution was somewhat similar to that at the beach of Slovenia, where the highest frequency of size was $250-1000 \mu \mathrm{m}$ and 2000-3000 $\mu \mathrm{m}$ (Laglbauer et al., 2014). However, in some other areas, shorter fibers were the more important fraction, for instance, in the Spanish Mediterranean continental shelf, $61 \%$ of fibers were 500 $1000 \mu \mathrm{m}$ (Filgueiras et al., 2019), or in the Venice lagoon of Italy, $93 \%$ of fibers was in the range $30-500 \mu \mathrm{m}$ while longer fibers (about $2500 \mu \mathrm{m}$ ) were rarely observed (Vianello et al., 2013).

The diameter of the fibers in our study size was quite small, a median of $18 \mu \mathrm{m}$ and a mean of $19.58 \pm 9.27 \mu \mathrm{m}$ (Fig. 6), in comparison to that reported in the other beach areas such as the northern coast of Taiwan (approximately $30 \mu \mathrm{m}$; Kunz et al., 2016), McCormack's Beach and Rainbow Haven Beach in Canada (several hundred micrometers; Mathalon and Hill, 2014) or the Germany beach (a few dozen micrometers; Dekiff et al., 2014).

\subsection{Potential impact to the biota}

The occurrence of a large number of synthetic fibers in the coastal environment is a danger to organisms in the marine ecosystems since they may accidentally or intentionally enter their body (Andrady, 2011). Especially, small-size synthetic fibers may pose more threat than large fibers to lower trophic organisms as these organisms capture any particles of appropriate size without selection. Meanwhile, higher trophic organisms could ingest microplastics by mistaking plastic for their prey (Wright et al., 2013; Moore et al., 2001). Synthetic fibers were reported to be the most dominant type of MPs in the body of many species such as zooplankton (70\% of the total MPs; Sun et al., 2017), bivalves ( > 50\% - 84.1\%; Li et al., 2015; Ding et al., 2018; Rochman et al.. 2015); fishes (65.8\% - 96\%; Neves et al., 2015; Pazos et al.. 2017). A study by Amelineau et al. (2016) stated that $100 \%$ of gular pouch samples contained plastic filaments, whereas fragments were only found in from $33 \%-55 \%$ of the total gular pouches.

Fisheries and aquaculture in Da Nang also play an important role in the city's economy and is identified as one of six important marine economic sectors with total annual catches of seafood are from 33,909 tons (in 2015) - 37,530 tons (in 2019) (DSO (Danang Statistical Office), $\underline{2020})$. The presence of synthetic fibers in the Da Nang coastal sediment poses a threat to the accumulation of these microplastics in aquatic species, especially deposit and suspension feeders that are reared in $\mathrm{Da}$ Nang beaches sediments. Although there have been no studies on MPs accumulation in these species in Da Nang, other pollutants such as heavy metals $(\mathrm{Pb}$ and $\mathrm{Cd})$ and organotin compounds were detected in some bivalves species from Da Nang coastal habitats (Midorikawa et al., 2004; Nguyen et al., 2015). Besides, the presence of MPs in many bivalve species of economic value living in beach sediment was also reported in many coastal areas, including Viet Nam. Mathalon and Hill (2014) detected an average of 178 microfibres per farmed mussel and 126 microfibres per wild mussel in the intertidal ecosystem surrounding Halifax Harbor, Nova Scotia, Canada. In Vietnam, the bivalves Perna Viridis was reported by Phuong et al. (2019) to contain an average microplastic concentration of 2.60 items/individual and 0.29 items $/ \mathrm{g}$ of wet tissue. The presence of MPs in seafood presents a hazard to food safety of humans, not only the local community but also tourists and people in seafood importing countries, as a calculation of Van Cauwenberghe and Janssen (2014), the annual dietary exposure for European shellfish consumers can amount to 11,000 microplastics per year.

\section{Conclusions}

Microplastic concentrations measured in Da Nang sediment beaches were rather high compared to those in worldwide beaches, even considering the bias induced by different methodologies. It demonstrated that Da Nang beaches are facing serious microplastic pollution. Synthetic fibers were identified as the most important shape (99.2\%) with a large majority of them (81.9\%) ranging in the size range 300 $2600 \mu \mathrm{m}$, which could potentially harm both marine and humans health. We assumed that the main sources of synthetic fibers are the domestic wastewaters from the inland population and resorts nearby as well as industrial wastewater discharges. Further investigations are required to better quantify and qualify the release of microplastics from those sources in order to have a robust baseline for effective management mitigation.

\section{Funding}

This research did not receive any specific grant from funding agencies in the public, commercial, or not-for-profit sectors.

\section{CRediT authorship contribution statement}

Tran Nguyen Quynh Anh: Writing - original draft, Writing - review \& editing, Visualization. Y. Nguyen Hoai Nhu: Investigation. Emilie Strady: Methodology, Writing - review \& editing. Nguyen Quy Tuan: Methodology, Investigation, Resources. Trinh-Dang Mau: Software, Validation, Formal analysis, Data curation, Project administration. Vo Van Minh: Conceptualization, Resources, Supervision.

\section{Declaration of competing interest}

The authors declare that they have no known competing financial interests or personal relationships that could have appeared to influence the work reported in this paper.

\section{Acknowledgments}

We would like to thank the Faculty of Biology and Environmental Science, the Faculty of Chemistry, University of Science and Education The University of $\mathrm{Da}$ Nang, and the COMPOSE project, funded by French MEAE and conducted by IRD and French Embassy in Vietnam for providing research facilities.

\section{References}

Abidli, S., Toumi, H., Lahbib, Y., Trigui El Menif, N., 2017. The first evaluation of microplastics in sediments from the complex Lagoon-Channel of Bizerte (northern Tunisia). Water Air Soil Pollut. 228, 262. https://doi.org/10.1007/s11270-0173439-9.

Abidli, S., Antunes, J.C., Ferreira, J.L., Lahbib, Y., Sobral, P., Trigui El Menif, N., 2018. Microplastics in sediments from the littoral zone of the north Tunisian coast (Mediterranean Sea). Estuar. Coast. Shelf Sci. 205, 1-9. https://doi.org/10.1016/j. ecss.2018.03.006

Amelineau, F., Bonnet, D., Heitz, O., Mortreux, V., Harding, A.M.A., Karnovsky, N., Walkusz, W., Fort, J., Gremillet, D., 2016. Microplastic pollution in the Greenland Sea: background levels and selective contamination of planktivorous diving seabirds. Environ. Pollut. 219,1131-1139. https://doi.org/10.1016/i.envpol.2016.09.017.

Andrady, A.L., 2011. Microplastics in the marine environment. Mar. Pollut. Bull. 62 , 1596-1605. https://doi.org/10.1016/j.marpolbul.2011.05.030.

Aslam, H., Ali, T., Mortula, M.M., Attaelmanan, A.G., 2020. Evaluation of microplastics in beach sediments along the coast of Dubai, UAE. Mar. Pollut. Bull. 150, 110739 https://doi.org/10.1016/j.marpolbul.2019.110739.

Balasubramaniam, M., Phillott, A.D., 2016. Preliminary observations of microplastics from beaches in the Indian ocean. Indian Ocean Turtle Newsletter 23, 13-16.

Blumenröder, J., Sechet, P., Kakkonen, J.E., Hartl, M.G.J., 2017. Microplastic contamination of intertidal sediments of Scapa flow, Orkney: a first assessment. Mar. Pollut. Bull. 124 (1), 112-120. https://doi.org/10.1016/j.marpolbul.2017.07.009.

Browne, M.A., Galloway, T., Thompson, R., 2007. Microplastic - an emerging contaminant of potential concern? Integr. Environ. Assess. Manag. 3, 559-561. https:// doi.org/10.1002/ieam.5630030412.

Browne, M.A., Crump, P., Niven, S.J., Teuten, E., Tonkin, A., Galloway, T., Thompson, R., 2011. Accumulation of microplastic on shorelines worldwide: sources and sinks. Environ. Sci. Technol. 45, 9175-9179. https://doi.org/10.1021/es201811s.

Carson, H.S., Colbert, A.L., Kaylor, M.J., Mc Dermid, K.J., 2011. Small plastic debris changes water movement and heat transfer through beach sediments. Mar. Pollut. Bull. 62, 1708-1713. https://doi.org/10.1016/j.marpolbul.2011.05.032.

Claessens, M., De Meester, S., Van Landuyt, L., De Clerck, K., Janssen, C.R., 2011. Occurrence and distribution of microplastics in marine sediments along the Belgian coast. Mar. Pollut. Bull. 62, 2199-2204. https://doi.org/10.1016/i.marpolbul.2011. 
$\underline{06.030}$

Cole, M., Lindeque, P., Fileman, E., Halsband, C., Goodhead, R.M., Moger, J., Galloway, T., 2013. Microplastic ingestion by zooplankton. Environ. Sci. Technol. 47 (12), 6646-6655. https://doi.org/10.1021/es400663f

Cole, M., Lindeque, P., Fileman, E., Halsband, C., Galloway, T., 2015. The impact of polystyrene microplastics on feeding, function and fecundity in the marine copepod Calanus helgolandicus. Environ. Sci. Technol. 49 (2), 1130-1137. https://doi.org/10. 1021/es504525u.

Constant, M., Kerhervéa, P., Mino-Vercellio-Verolleta, M., Dumontier, M., Vidal, A.S., Canals, M., Heussner, S., 2019. Beached microplastics in the northwestern Mediterranean Sea. Mar. Pollut. Bull. 142, 263-273. https://doi.org/10.1016/j. marpolbul.2019.03.032

Da Nang DONRE (Department of Natural Resources and Environment Da Nang), 2018. Current State of the Environment in Da Nang Report, Vietnam. pp. 97.

Da Nang URENCO (Da Nang Urban Environment Company), 2019. Solid wastes Management in Da Nang, Viet Nam. Foundations for source-to-sea management. In: Addressing Solid Waste in the Vu Gia - Thu bon River Basin. Oral Presentation, Stakeholder Workshop, November 2019, Hoi an, Vietnam

De Falco, F., Gullo, M.P., Gentile, G., Di Pace, E., Cocca, M., Gelabert, L., Brouta-Agnésa, M., Rovira, A., Escudero, R., Villalba, R., Mossotti, R., Montarsolo, A., Gavignano, S Tonin, C., Avella, M., 2018. Evaluation of microplastic release caused by textile washing processes of synthetic fabrics. Environ. Pollut. 236, 916-925. https://doi. org/10.1016/j.envpol.2017.10.057.

Dehaut, A., Hermabessiere, L., Duflos, G., 2019. Current frontiers and recommendations for the study of microplastics in seafood. Trends Anal. Chem. 116, 346-359. https:// doi.org/10.1016/j.trac.2018.11.011.

Dekiff, J.H., Remy, D., Klasmeier, J., Fries, E., 2014. Occurrence and spatial distribution of microplastics in sediments from Norderney. Environ. Pollut. 186, 248-256. https://doi.org/10.1016/j.envpol.2013.11.019

Ding, J.F., Li, J.X., Jun, C.J., He, C.F., Jiang, F.H., Gao, F.L., Zheng, L., 2018. Separation and identification of microplastics in digestive system of bivalves. Chin. J. Anal. Chem. 46 (5), 690-697. https://doi.org/10.1016/S1872-2040(18)61086-2.

DSO (Danang Statistical Office), 2020. Da Nang City Statistical Yearbook 2019. Statistical Publishing House, Vietnam, pp. 619.

Eo, S., Hong, S.H., Song, Y.K., Lee, J., Lee, J., Shim, W.J., 2018. Abundance, composition and distribution of microplastics larger than $20 \mu \mathrm{m}$ in sand beaches of South Korea. Environ. Pollut. 238, 894-902. https://doi.org/10.1016/j.envpol.2018.03.096.

Esiukova, E., 2017. Plastic pollution on the Baltic beaches of Kaliningrad region, Russia Mar. Pollut. Bull. 114, 1072-1080. https://doi.org/10.1016/i.marpolbul.2016.10. 001

Filgueiras, A.V., Gago, J., Campillo, J.A., León, V.M., 2019. Microplastic distribution in surface sediments along the Spanish Mediterranean continental shelf. Environ. Sci. Pollut. Res. 26, 21264-21273. https://doi.org/10.1007/s11356-019-05341-5.

Filho, J.E.M., Monteiro, R.C.P. 2019. Widespread microplastics distribution at an Amazon macrotidal sandy beach. Mar. Pollut. Bull. 145, 219-223. https://doi.org/ 10.1016/j.marpolbul.2019.05.049.

Fischer, E.K., Paglialonga, L., Czech, E., Tamminga, M., 2016. Microplastic pollution in lakes and Lake shoreline sediments - a case study on Lake Bolsena and Lake Chius (Central Italy). Environ. Pollut. 213, 648-657. https://doi.org/10.1016/j.envpol. 2016.03.012.

Fok, L., Cheung, P.K., 2015. Hong Kong at the Pearl River estuary: a hotspot of microplastic pollution. Mar. Pollut. Bull. 99 (1-2), 112-118. https://doi.org/10.1016/j. marpolbul.2015.07.050.

Free, C.M., Jensen, O.P., Mason, S.A., Eriksen, M., Williamson, N.J., Boldgiv, B., 2014 High-levels of microplastic pollution in a large, remote, mountain lake. Mar. Pollut. Bull. 85, 156-163. https://doi.org/10.1016/j.marpolbul.2014.06.001.

Frias, J.P.G.L., Nash, R., 2019. Microplastics: finding a consensus on the definition. Mar Pollut. Bull. 138, 145-147. https://doi.org/10.1016/i.marpolbul.2018.11.022.

GESAMP, 2019. In: Kershaw, P.J., Turra, A., Galgani, F. (Eds.), Guidelines or the Monitoring and Assessment of Plastic Litter and Microplastics in the Ocean. GESAMP Joint Group of Experts on the Scientific Aspects of Marine Environmental Protection, London, UK, pp. 130. https://doi.org/10.25607/OBP-435.

Gogina, E., Quan, T.H., 2018. The assessment of technology SBRin Vietnamese wastewater treatment. IOP Conference Series: Materials Science and Engineering 365, 022061. https://doi.org/10.1088/1757-899X/365/2/022061.

He, P., Chen, L., Shao, L., Zhang, H., Lü, F., 2019. Municipal solid waste (MSW) landfill: source of microplastics? Evidence of microplastics in landfill leachate. Water Res. 159, 38-45. https://doi.org/10.1016/j.watres.2019.04.060.

Hidalgo-Ruz, V., Gutow, L., Thompson, R.C., Thiel, M., 2012. Microplastics in the marine environment: a review of the methods used for identification and quantification. Environ. Sci. Technol. 46, 3060-3075. https://doi.org/10.1021/es2031505.

Horton, A.A., Walton, A., Spurgeon, D.J., Lahive, E., Svendsen, C., 2017. Microplastics in freshwater and terrestrial environments: evaluating the current understanding to identify the knowledge gaps and future research priorities. Sci. Total Environ. 586, 127-141. https://doi.org/10.1016/j.scitotenv.2017.01.190.

IUCN, 2019. Plastic Waste Pollution in Vietnam, Meeting Presentation, Project "Ocean Plastic Turned into an Opportunity in Circular Economy - OPTOCE", ho chi Minh City, Vietnam, October 4, 2019.pp. 24

Jambeck, J.R., Geyer, R., Wilcox, C., Siegler, T.R., Perryman, M., Andrady, A., Narayan, R., Law, K.L., 2015. Plastic waste inputs from land into the ocean. Science 347 (6223), 768-771. https://doi.org/10.1126/science.1260352.

Kunz, A., Walther, B.A., Löwemark, L., Lee, Y.-C., 2016. Distribution and quantity of microplastic on sandy beaches along the northern coast of Taiwan. Mar. Pollut. Bull. 111 (1-2), 126-135. https://doi.org/10.1016/j.marpolbul.2016.07.022.

Laglbauer, B.J.L., Franco-Santos, R.M., Andreu-Cazenave, M., Brunelli, L., Papadatou, M., Palatinus, A., Grego, M., Deprez, T., 2014. Macrodebris and microplastics from beaches in Slovenia. Mar. Pollut. Bull. 89, 356-366. https://doi.org/10.1016/j. marpolbul.2014.09.036.

Lahens, L., Strady, E., Kieu-Le, T.-C., Dris, R., Boukerma, K., Rinnert, E., Gasperi, J., Tassin, B., 2018. Macroplastic and microplastic contamination assessment of a tropical river (Saigon River, Vietnam) transversed by a developing megacity. Environ. Pollut. 236, 661-671. https://doi.org/10.1016/i.envpol.2018.02.005.

Le, A.T., 2009. Assessment of the Natural Resources of Da Nang for Sustainable Development. Master Thesis. Hanoi National University, Natural Science University. Vietnam, pp. 106

Lee, K.W., Shim, W.J., Kwon, O.Y., Kang, J.-H., 2013. Size-dependent effects of micro polystyrene particles in the marine copepod Tigriopus japonicus. Environ. Sci. Technol. 47, 11278-11283. https://doi.org/10.1021/es401932b.

Li, J., Yang, D., Li, L., Jabeen, K., Shi, H., 2015. Microplastics in commercial bivalves from China. Environ. Pollut. 207, 190-195. https://doi.org/10.1016/i.envpol.2015.09. $\underline{018}$

Liebezeit, G., Dubaish, F., 2012. Microplastics in beaches of the EastFrisian Islands Spiekeroog and Kachelotplate. Bull. Environ. Contam. Toxicol. 89 (1), 213-217. https://doi.org/10.1007/s00128-012-0642-7.

Lo, H.K.A., Chan, K.Y.K., 2018. Negative effects of microplastic exposure on growth and development of Crepidula onyx. Environ. Pollut. 233, 588-595. https://doi.org/10. 1016/i.envpol.2017.10.095

Lo, H., Xu, X., Wong, C., Cheung, S., 2018. Comparisons of microplastic pollution between mudflats and sandy beaches in Hong Kong. Environ. Pollut. 236, 208-217. https:// doi.org/10.1016/i.envpol.2018.01.031.

Lönnstedt, O.M., Eklöv, P., 2016. Environmentally relevant concentrations of microplastic particles influence larval fish ecology. Science 352 (6290), 1213-1216. https://doi. org/10.1126/science.aad8828.

Lots, F.A., Behrens, P., Vijver, M.G., Horton, A.A., Bosker, T., 2017. A large-scale investigation of microplastic contamination: abundance and characteristics of micro plastics in European beach sediment. Mar. Pollut. Bull. 123, 219-226. https://doi. org/10.1016/j.marpolbul.2017.08.057.

Luan, L., Wang, X., Zheng, H., Liu, L., Luo, X., Li, F., 2019. Differential toxicity of func tionalized polystyrene microplastics to clams (Meretrix meretrix) at three key development stages of life history. Mar. Pollut. Bull. 139, 346-354. https://doi.org/10. 1016/j.marpolbul.2019.01.003.

Lusher, A.L., Hollman, P.C.H., Mendoza-Hill, J.J., 2017. Microplastics in fisheries and aquaculture: Status of knowledge on their occurrence and implications for aquatic organisms and food safety. In: FAO Fisheries and Aquaculture Technical Paper 615, Rome, Italy.

Martins, J., Sobral, P., 2011. Plastic marine debris on the Portuguese coastline: a matter of size? Mar. Pollut. Bull. 62, 2649-2653. https://doi.org/10.1016/j.marpolbul.2011. 09.028.

Masura, J., Baker, J., Foster, G., Arthur, C., 2015. Laboratory methods for the analysis of microplastics in the marine environment: recommendations for quantifying synthetic particles in waters and sediments. NOAA Technical Memorandum 48, 31.

Mathalon, A., Hill, P., 2014. Microplastic fibers in the intertidal ecosystem surrounding Halifax harbor, Nova Scotia. Mar. Pollut. Bull. 81 (1), 69-79. https://doi.org/10. 1016/i.marpolbul.2014.02.018.

Matsuguma, Y., Takada, H., Kumata, H., Kanke, H., Sakurai, S., Suzuki, T., Itoh, M., Okazaki, Y., Boonyatumanond, R., Zakaria, M.P., Weerts, S., Newman, B., 2017. Microplastics in sediment cores from Asia and Africa as indicators of temporal trends in plastic pollution. Arch. Environ. Contam. Toxicol. 73, 230-239. https://doi.org/ 10.1007/s00244-017-0414-9.

Midorikawa, S., Arai, T., Harino, H., Nguyen, D.C., Pham, A.D., Miyazaki, N., 2004. Organotin levels in bivalves in Southeast Asia. Coast. Mar. Sci. 29 (1), 57-62.

Moore, C.J., Moore, S.L., Leecaster, M.K., Weisberg, S.B., 2001. A comparison of plastic and plankton in the North Pacific central gyre. Mar. Pollut. Bull. 42 (12), 1297-1300. https://doi.org/10.1016/S0025-326X(01)00114-X.

Napper, I.E., Thompson, R.C., 2016. Release of synthetic microplastic plastic fibers from domestic washing machines: effects of fabric type and washing conditions. Mar. Pollut. Bull. 112, 39-45. https://doi.org/10.1016/i.marpolbul.2016.09.025.

Nel, H.A., Froneman, P.W., 2015. A quantitative analysis of microplastic pollution along the south-eastern coastline of South Africa. Mar. Pollut. Bull. 101, 274-279. https:// doi.org/10.1016/j.marpolbul.2016.09.025.

Nelms, S.E., Galloway, T.S., Godley, B.J., Jarvis, D.S., Lindeque, P.K., 2018. Investigating microplastic trophic transfer in marine top predators. Environ. Pollut. 238, 999-1007. https://doi.org/10.1016/i.envpol.2018.02.016.

Nelms, S.E., Barnett, J., Brownlow, A., Davison, N.J., Deaville, R., Galloway, T.S., Lindeque, P.K., Santillo, D., Godley, B.J., 2019. Microplastics in marine mammals stranded around the British coast: ubiquitous but transitory? Sci. Rep. 9, 1075. https://doi.org/10.1038/s41598-018-37428-3.

Neves, D., Sobral, P., Ferreira, J.L., Pereira, P., 2015. Ingestion of microplastics by commercial fish off the Portuguese coast. Mar. Pollut. Bull. 101 (1), 119-126. https://doi.org/10.1016/j.marpolbul.2015.11.008.

$\mathrm{Ng}$, K.L., Obbard, J.P., 2006. Prevalence of microplastics in Singapore's coastal marine environment. Mar. Pollut. Bull. 52 (7), 761-767. https://doi.org/10.1016/i. marpolbul.2005.11.017.

Nguyen, V.K., Tran, D.V., Okubo, K., Kieu, T.K., Duong, C.V., 2015. Assessment of lead and cadmium contamination by sediments and bivalve species from the estuaries in Da Nang city, Vietnam. J. Environ. Sci. Sustainable Soc. 6, 1-6. https://doi.org/10. 3107/jesss.6.1

Nor, N.H.M., Obbard, J.P., 2014. Microplastics in Singapore's coastal mangrove ecosystems. Mar. Pollut. Bull. 79, 278-283. https://doi.org/10.1016/j.marpolbul.2013.11. $\underline{025}$

Pazos, R.S., Maiztegui, T., Colautti, D.C., Paracampo, A.H., 2017. Microplastics in gut contents of coastal freshwater fish from Río de la Plata estuary. Mar. Pollut. Bull. 122 
(1-2), 85-90.https://doi.org/10.1016/j.marpolbul.2017.06.007.

Phuong, N.N., Pham, Q.T., Duong, T.T., Le, T.P.Q., Amiard, F., 2019. Contamination of microplastic in bivalve: first evaluation in Vietnam. Vietnam J. Earth Sci. 41 (3), 252-258. https://doi.org/10.15625/0866-7187/41/3/13925.

Piñon-Colin, T.J., Rodriguez-Jimenez, R., Pastrana-Corral, M.A., Rogel-Hernandez, E., Wakida, F.T., 2018. Microplastics on sandy beaches of the Baja California peninsula, Mexico. Mar. Pollut. Bull. 131 (A), 63-71. https://doi.org/10.1016/j.marpolbul. 2018.03.055.

Popa, M., Morar, D., Adrian, T., Teusdea, A.C., Popa, D., 2014. Study concerning the pollution of the marine habitats with the microplastic fibres. J. Environ. Prot. Ecol. 15 (3), 916-923.

Provencher, J.F., Vermaire, J.C., Avery-Gomm, S., Braune, B.M., Mallory, M.L., 2018. Garbage in guano? Microplastic debris found in faecal precursors of seabirds known to ingest plastics. Sci. Total Environ. 644, 1477-1484. https://doi.org/10.1016/i. scitotenv.2018.07.101.

Qiu, Q., Peng, J., Yu, X., Chen, F., Wang, J., Dong, F., 2015. Occurrence of microplastics in the coastal marine environment: first observation on sediment of China. Mar. Pollut. Bull. 98 (1-2), 274-280. https://doi.org/10.1016/j.marpolbul.2015.07.028.

R Core Team, 2018. R: A Language and Environment for Statistical Computing. R Foundation for Statistical Computing, Vienna, Austria. https://www.R-project.org/.

Reis, P.I.N., 2019. Microplastic Contamination in Argentina: Insights about a Source (Wastewater Treatment Plant) and a Sink (Beach): 2 Case Studies. Master Thesis. School of Agriculture. University of Lisbon. Portugal, pp. 80.

Ritchie, H., Roser, M., 2018. Plastic pollution. Published online at OurWorldlnData.org. Retrieved from. https://ourworldindata.org/plastic-pollution.

Rochman, C.M., Tahir, A., Williams, S.L., Baxa, D.V., Lam, R., Miller, J.T., Teh, F.C., Werorilangi, S., The, S.J., 2015. Anthropogenic debris in seafood: plastic debris and fibers from textiles in fish and bivalves sold for human consumption. Sci. Rep. 5, 14340. https://doi.org/10.1038/srep14340.

Ryan, P.G., Moore, C.J., Van Franeker, J.A., Moloney, C.L., 2009. Monitoring the abundance of plastic debris in the marine environment. Phil. Trans. R. Soc. B 364 (1526), 1999-2012. https://doi.org/10.1098/rstb.2008.0207.

Setälä, O., Norkko, J., Lehtiniemi, M., 2016. Feeding type affects microplastic ingestion in a coastal invertebrate community. Mar. Pollut. Bull. 102, 95-101. https://doi.org/10. 1016/i.marpolbul.2015.11.053.

Shim, W.J., Hong, S.H., Eo, S., 2018. Marine microplastics: Abundance, distribution, and composition. In: Microplastic Contamination in Aquatic Environments. Elsevier, pp. 1-26. https://doi.org/10.1016/B978-0-12-813747-5.00001-1.

Stolte, A., Forster, S., Gerdts, G., Schubert, H., 2015. Microplastic concentrations in beach sediments along the German Baltic coast. Mar. Pollut. Bull. 99, 216-229. https://doi. org/10.1016/..marpolbul.2015.07.022.

Strady, E., Kieu-Le, T.-C., Gasperi, J., Tassin, B., 2020. Temporal dynamic of anthropogenic fibers in a tropical river-estuarine system. Environ. Pollut. 259, 113897 https://doi.org/10.1016/i.envpol.2019.113897.

Sun, X., Li, Q., Zhu, M., Lian, J., Zheng, S., Zhao, Y., 2017. Ingestion of microplastics by natural zooplankton groups in the northern South China Sea. Mar. Pollut. Bull. 115 217-224. https://doi.org/10.1016/j.marpolbul.2016.12.004

Thach, P., Nguyen, D.A., 2010. Geography of Quang Nam - Da Nang. Social Sciences
Publishing House, Hanoi, Vietnam 1888.

Thompson, R.C., Moore, C.J., vom Saal, F.S., Swan, S.H., 2009. Plastics, the environment and human health: current consensus and future trends. Phil. Trans. R. Soc. B 364 (1526), 2153-2166.https://doi.org/10.1098/rstb.2009.0053.

Tiwari, M., Rathod, T.D., Ajmal, P.Y., Bhangare, R.C., Sahu, S.K., 2019. Distribution and characterization of microplastics in beach sand from three different Indian coastal environments. Mar. Pollut. Bull. 140, 262-273. https://doi.org/10.1016/i. marpolbul.2019.01.055.

Tran, T.H., 2019. Project Report "Survey on the Current Status of Plastic Waste in Vietnam". WWF, Vietnam, pp. 40

Turra, A., Manzano, A.B., Dias, R.J.S., Mahiques, M.M., Barbosa, L., Balthazar-Silva, D., Moreira, F.T., 2014. Three-dimensional distribution of plastic pellets in Sandy beaches: shifting paradigms. Sci. Rep. 4, 4435. https://doi.org/10.1038/srep04435.

Van Cauwenberghe, L., Janssen, C.R., 2014. Microplastics in bivalves cultured for human consumption. Environ. Pollut. 193, 65-70. https://doi.org/10.1016/i.envpol.2014. 06.010 .

Van Cauwenberghe, L., Claessens, M., Vandegehuchte, M., Janssen, C.R., 2015. Microplastics are taken up by mussels (Mytilus edulis) and lugworms (Arenicola marina) living in natural habitats. Environ. Pollut. 199, 10-17. https://doi.org/10. 1016/i.envpol.2015.01.008.

Vendel, A.L., Bessa, F., Alves, V.E.N., Amorim, A.L.A., Patrício, J., Palma, A.R.T., 2017. Widespread microplastic ingestion by fish assemblages in tropical estuaries subjected to anthropogenic pressures. Mar. Pollut. Bull. 117 (1-2), 448-455. https://doi.org/ 10.1016/i.marpolbul.2017.01.081.

Vianello, A., Boldrin, A., Guerriero, P., Moschino, V., Rella, R., Sturaro, A., Da Ros, L., 2013. Microplastic particles in sediments of lagoon of Venice, Italy: first observations on occurrence, spatial patterns and identification. Estuar. Coast. Shelf Sci. 130 , 54-61. https://doi.org/10.1016/j.ecss.2013.03.022.

Waldschlager, K., Schüttrumpf, H., 2019. Effects of particle properties on the settling and rise velocities of microplastics in freshwater under laboratory conditions. Environ. Sci. Technol. 53, 1958-1966. https://doi.org/10.1021/acs.est.8b06794.

Wang, F., Wong, C.S., Chen, D., Lu, X., Wang, F., Zeng, E.Y., 2018. Interaction of toxic chemicals with microplastics: a critical review. Water Res. 139, 208-219. https://doi. org/10.1016/j.watres.2018.04.003.

Wang, J., Lia, Y., Lu, L., Zheng, M., Zhang, X., Tian, H., Wang, W., Ru, S., 2019. Polystyrene microplastics cause tissue damages, sex-specific reproductive disruption and transgenerational effects in marine medaka (Oryzias melastigma). Environ. Pollut. 254 (B), 1-40.

Wright, S.L., Thompson, R.C., Galloway, T.S., 2013. The physical impacts of microplastics on marine organisms: a review. Environ. Pollut. 178, 483-492. https://doi.org/10. 1016/i.envpol.2013.02.031

Yu, X., Peng, J., Wang, J., Wang, K., Bao, S., 2016. Occurrence of microplastics in the beach sand of the Chinese inner sea: The Bohai Sea. Environ. Pollut. 214, 722-730. https://doi.org/10.1016/i.envpol.2016.04.080.

Yu, X., Ladewig, S., Bao, S., Toline, C.A., Whitmire, S., Chow, A.T., 2018. Occurrence and distribution of microplastics at selected coastal sites along the southeastern United States. Sci. Total Environ. 613, 298-305. https://doi.org/10.1016/j.scitotenv.2017. $\underline{09.100}$. 